\title{
DIAGNÓSTICO DOS SISTEMAS ANTRÓPICOS E USO E OCUPAÇÃO DO MUNICÍPIO DE ALCOBAÇA (BA)
}

\author{
Pedro Spanghero \\ Universidade Estadual de Campinas, Instituto de Geociências, Campinas, SP, Brasil \\ geo.pedros@gmail.com \\ Samuel Macedo \\ Universidade Estadual de Santa Cruz, Departamento de Ciências Agrárias e Ambientais, Ilhéus, BA,Brasil \\ macedo.samuel@yahoo.com \\ Ralph Charles
Universidade Estadual de Campinas, Instituto de Geociências, Campinas, SP, Brasil
cralph001@yahoo.fr \\ Regina Celia de Oliveira \\ Universidade Estadual de Campinas, Instituto de Geociências, Campinas, SP, Brasil \\ $\underline{\text { reginacoliveira@ige.unicamp.br }}$
}

\begin{abstract}
RESUMO
As regiões litorâneas constituem-se em áreas de grande fragilidade e vulnerabilidade devido aos processos naturais e a relação secular de ocupação destas zonas. As ações antrópicas podem resultar em danos irreversíveis; exemplos de danos aos ambientes costeiros são observados em todo o litoral brasileiro que impulsionam os conflitos de ordem ambiental e social. Em virtude deste cenário, este trabalho tem como objetivo de promover um processo de ordenamento de uso e ocupação do município de Alcobaça de forma eficaz a partir da execução de uma análise dos sistemas naturais na escala 1:50.000 utilizando a metodologia proposta por Rodriguez, Silva e Cavalcanti (2013), da Geoecologia da Paisagem, que a partir da articulação dos componentes antrópicos da paisagem foi possível identificar a predominância de dois vetores econômicos que predominam na polarização territorial em Alcobaça com grandes avanços. Os resultados mostram mudanças de forma significativa na dinâmica de uso e ocupação no município de Alcobaça durante os últimos anos. A vulnerabilidade social do município de Alcobaça, alinhada ao processo de monopolização do território por parte da monocultura de eucalipto desde o final da década de 1970, foi responsável pela elevada taxa de desemprego estrutural.
\end{abstract}

Palavras-chave: Sistemas antrópicos. Análise sistémica. Município de Alcobaça/BA.

\section{DIAGNOSIS OF THE ANTHROPIC SYSTEMS OF THE MUNICIPALITY OF ALCOBAÇA}

(BA)

\begin{abstract}
Coastal regions are areas of great fragility and vulnerability due to natural processes and the secular relationship of occupation of these zones. Anthropic actions may result in irreversible damage; Examples of damage to coastal environments are observed in all the Brazilian coast boosting environmental and social conflicts. Due to this scenario, this research aims to promote a process of effective use and occupation of the municipality of Alcobaça adopting analysis scale 1:50,000 of natural systems using the methodology proposed by Rodriguez, Silva and Cavalcanti (2013), from Landscape Geoecology, that from the articulation of the anthropic components of the landscape it was possible to identify the predominance of two economic vectors that predominate in the territorial polarization in Alcobaça with great advances. The main results show significant changes in the dynamics of use and occupation in the municipality of Alcobaça during the last years. The social vulnerability of the municipality of Alcobaça, aligned with the monopolization process of the territory by eucalyptus monoculture since the end of 1970 decade, was responsible for the high rate of structural unemployment.
\end{abstract}

Key words: Antropic systems. Systemic analysis. Municipality of Alcobaça/BA.

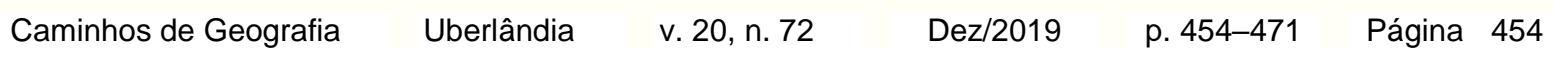




\section{INTRODUÇÃO}

As regiões litorâneas apresentam diversas fisionomias paisagísticas, compostas por feições morfológicas que variam de acordo com a latitude, geologia, clima, descarga fluvial, diversidades pedológicas e de fauna e flora, apresentando grande complexidade. Nestas áreas encontra-se grande parte da população brasileira, o que torna necessária a realização de diagnósticos e prognósticos integrados para o ordenamento e uso racional dos recursos naturais, garantindo a manutenção dos serviços ambientais e da biodiversidade. Essas regiões apresentam grande fragilidade e vulnerabilidade por estarem em contato direto com as ações dos oceanos e do continente, além dos impactos de sua histórica ocupação humana (AMORIM, 2011).

O Brasil possui um dos maiores limites de costa do mundo, com cerca de $7.491 \mathrm{~km}$ de extensão (MIN, 2012), e o litoral da Bahia se destaca por ser o maior do país, com uma extensão de $1.181 \mathrm{~km}$, e possui grandes potenciais culturais, náuticos, esportistas, eco turísticos, dentre outros (NICOLODI, PETERMANN, 2010). Para fins de zoneamento foi elaborado em 1990 a regionalização do litoral baiano com o intuito de organizar intervenções públicas para o desenvolvimento de atividades turísticas através do planejamento regional (SETUR, 2019).

$\mathrm{Na}$ Costa do Descobrimento, Extremo Sul da Bahia, em 1960, em virtude do movimento de integração econômica e da industrialização no país, teve como marco principal a construção da BR101 inaugurada em 1973. Cortando a região em todo o seu comprimento, a BR-101 constituiria o grande divisor de águas na história regional, rompendo seu isolamento físico e econômico e contribuindo para um novo desenho espacial da área, com a redefinição da hierarquia da rede de cidades, ao mesmo tempo em que impulsiona uma série de transformações na estrutura econômica regional, marcada pela intensificação das atividades madeireira e pecuária, e, posteriormente, pelo desenvolvimento da monocultura de eucalipto, inserindo-a definitivamente no conjunto da economia nacional (PEDREIRA, 2008).

A infraestrutura rodoviária, a existência de terras de valor reduzido e as características naturais da região, em conjunto com o aporte de políticas públicas estaduais e federais, com fartas concessões de créditos e subsídios incentivados pelo BNDES, direcionaram para o setor agroflorestal, entre 1957 e 1991, cerca de $R \$ 1.805,19$ milhões. Isso proporcionou a disseminação de tecnologias e agregação de valor no setor industrial emergente que favoreceu a expansão da monocultura e o surgimento do complexo industrial de papel e celulose, agravando não somente as relações sociais no campo, mas também consolidando a apropriação privada do espaço por empresas multinacionais (CAR, 1994).

As primeiras unidades de produção de eucalipto surgiram na região Sul da Bahia na década de 1980, atraídas, para além da necessidade de reflorestamento, em função de relevantes fatores locacionais, segundo os estudos da SEI (2012), pelas condições edafoclimáticas, pelo preço da terra, por facilidade de escoamento da produção, disponibilidade de mão de obra e pelas grandes extensões de terras. Tais unidades instaladas contribuíram para o adensamento populacional e substituição da vegetação natural por silvicultura de eucalipto (SOUZA, 2017). A partir da entrada das atividades silviculturais, a região apresentou grandes transformações sociais.

Isso motivou cumprimento do objetivo geral do presente estudo que buscou promover um processo de ordenamento de uso e ocupação do município de Alcobaça de forma eficaz a partir da execução de uma análise dos sistemas naturais na escala 1:50.000 utilizando a metodologia proposta por Rodriguez, Silva e Cavalcanti (2013).

\section{MATERIAIS E MÉTODOS}

\section{Área de estudo}

O município de Alcobaça está localizado na Costa das Baleias, Extremo Sul do estado da Bahia, entre os paralelos $17^{\circ} 20^{\prime}$ e $17^{\circ} 40^{\prime}$ de latitude Sul e os meridianos 39¹0' e 3940' de longitude Oeste. Limita-se ao sul com o município de Caravelas, ao norte com o município de Prado, a oeste com município de Teixeira de Freitas e a leste com o Oceano Atlântico (Figura 1). Possui uma área de $1.482,28 \mathrm{~km}^{2}$ e em 2010 sua população era de 21.271 habitantes (IBGE, 2010). 
Figura 1 - Localização do município de Alcobaça, Bahia.

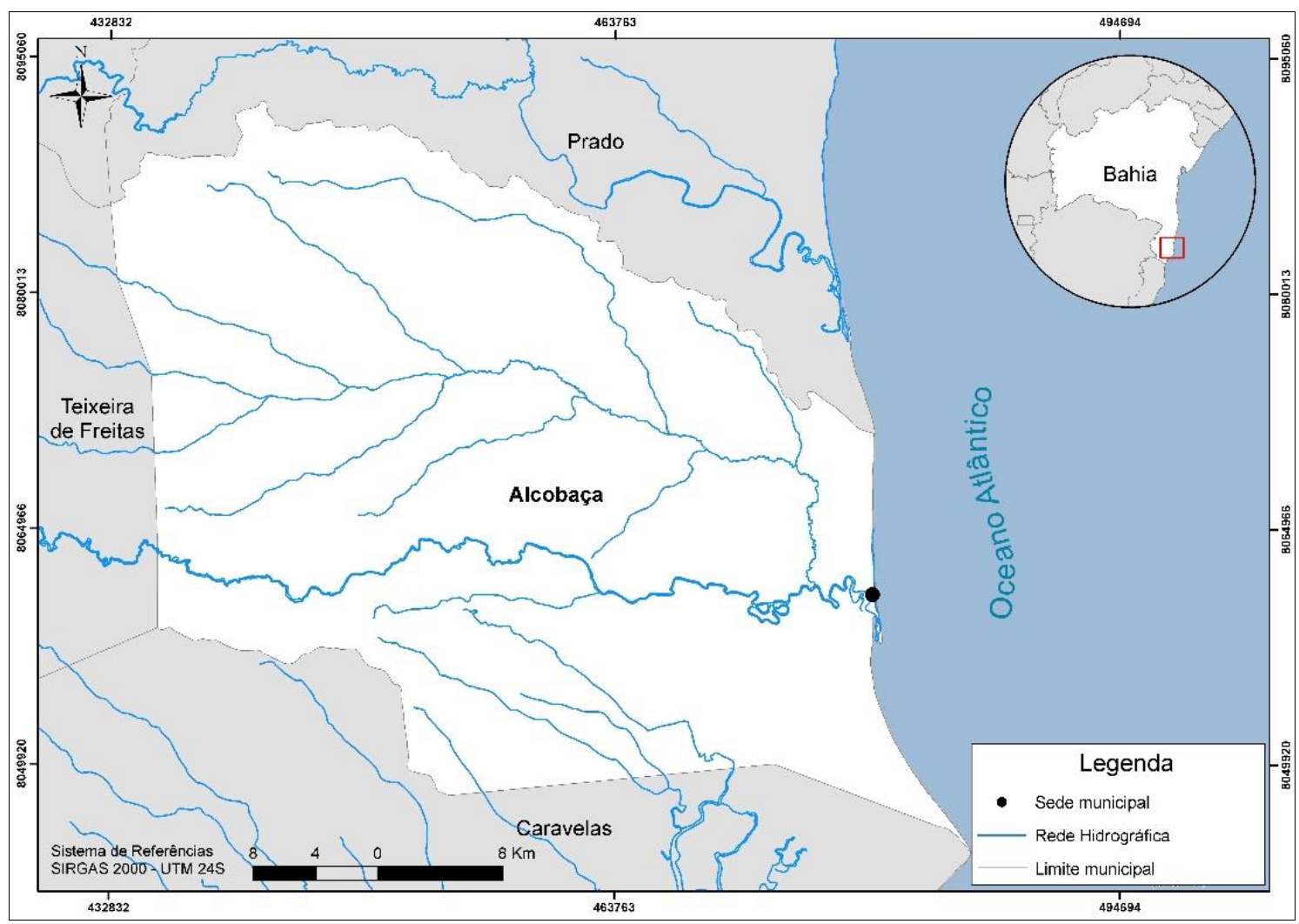

\section{METODOLOGIA}

Utilizou-se a metodologia proposta por Rodriguez, Silva e Cavalcanti (2013), parte da abordagem geossistêmica e envolve as seguintes etapas: organização do projeto, inventário dos componentes naturais, análise e diagnóstico.

Primeiramente, organizou-se o projeto através do levantamento de informações bibliográficas, a fim de subsidiar teoricamente a análise dos sistemas antrópicos. Em seguida buscaram-se dados secundários in situ e em diversas instituições de ensino e pesquisa, como a Universidade Estadual de Campinas (Unicamp) e Instituto Brasileiro de Geografia e Estatística (IBGE).

Após a organização do projeto foi necessário reconhecer a área de estudo em três etapas. A primeira em agosto de 2016, com apoio da Secretaria Municipal de Saúde e da Fundação Oswaldo Cruz na visitação das comunidades de São José, Aparajú, Taquari, Canta Galo, Pedra D'água I, Acampamento Palmeiras e Pouso Alegre. A segunda em dezembro de 2016, desenvolvido na planície costeira sul e norte do município de Alcobaça-BA. A terceira em janeiro, fevereiro e agosto de 2017 foi percorrida toda a porção interiorana do município, partindo da planície costeira e seguindo a oeste para os Tabuleiros Costeiros. Todos os trabalhos de campo tiveram como função identificar os aspectos fitogeográficos, conflitos e/ou tensões ambientais (desmatamento, ocupação irregular, ocupação de movimentos sociais). Todos os elementos foram registrados por levantamento fotográfico, marcados com ponto de Global Positioning System (GPS), e anotados em caderneta de campo.

Finalizada as três etapas do trabalho de campo, iniciou-se a fase de inventário dos dados cartográficos visando à constituição detalhada das características antrópicas do município de Alcobaça. A proposta metodológica de Rodriguez, Silva e Cavalcanti (2013) determina os principais parâmetros e dados a serem levantados e, portanto, iniciou-se a fase de inventário dos dados cartográficos com o objetivo de elaboração e organização de mapas.

O primeiro documento cartográfico de uso e ocupação da terra elaborado diz respeito ao mapeamento de uso e ocupação da terra do ano de 1977 na escala 1:100.000, com base na

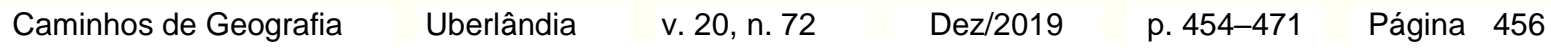


interpretação da imagem LandSat 2 de pixel $90 \mathrm{~m}^{2}$. Devido ao tamanho do pixel foi realizado a seguinte classificação: Área Florestal (Arbórea), Área Florestal (Arbustiva) e Pastagem.

O segundo documento elaborado refere-se aos mapeamentos de uso e ocupação da terra na escala 1:50.000 e pixel $30 \mathrm{~m}^{2}$ dos anos de 1984, 1994, $2006 \mathrm{com}$ base nas imagens de satélite do LandSat 5 e do ano de 2017, com base na análise da imagem disponibilizada do LandSat 8. Pelo tamanho menor dos pixels foi possível um melhor detalhamento nas classes, definidas a partir da adaptação do Manual Técnico do IBGE (2013) seguir: Área Urbanizada, Área Florestal (Arbórea), Área Florestal (Arbustiva), Área de Manguezais, Cultura Temporárias, Pastagem, Silvicultura de Eucalipto.

O procedimento de mapeamento adotado foi desenvolvido no software eCognition através da classificação supervisionada, sendo esta a segmentação orientada a objeto. Após a segmentação foi realizada uma avaliação visual dos arquivos gerados para avaliar o desempenho. Para isso os raster resultantes da segmentação foram transformados em arquivos vetores e em seguida importados para o ArcGis 10.4. As edições e correções foram realizadas todas manualmente através da interpretação e reconhecimento visual das imagens de satélite dos respectivos anos. Algumas classes tiveram o seu limite redefinido, outras foram divididas ou mudaram de classificação.

O último documento elaborado é resultado da interpretação mais apurada e detalhada, e houve a preocupação de buscar imagens de maior resolução por se tratar do documento base para a elaboração do mapa dos Sistemas Antrópicos.

O mapeamento de uso e ocupação da terra do ano de 2017, na escala 1:50.000, é resultante da interpretação visual das imagens RapidEye e Landsat 8 deste mesmo ano, adquiridas gratuitamente pelo site do Ministério do Meio Ambiente (MMA) e do Instituto Nacional de Pesquisas Espaciais (INPE). A classificação foi realizada no software ArcGis 10.4 de forma manual, através da interpretação visual das classes, levando-se em conta a textura, tonalidade e contexto. As classes definidas foram as seguintes: Área Urbanizada, Área Florestal (Arbórea), Área Florestal (Arbustiva), Áreas de Manguezais, Cultura Temporária, Mussununga, Pastagem, Silvicultura de Eucalipto.

Para análise e diagnóstico foi necessária a identificação dos sistemas antrópicos (Quadro 1), feita a partir do uso e da funcionalidade de cada um deles, permitindo que fosse realizada a subdivisão que consta no Quadro 1.

Quadro 1 - Sistemas antrópicos

\begin{tabular}{|c|c|}
\hline SISTEMAS ANTRÓPICOS & SUB-SISTEMAS \\
\hline \multirow{2}{*}{$\begin{array}{c}\text { Uso natural protegido } \\
\text { ou em conservação }\end{array}$} & Várzea/Área úmida \\
\cline { 2 - 2 } & Manguezal \\
\cline { 2 - 2 } Rurais & Vegetação Arbustiva e Arbórea \\
\cline { 2 - 2 } & Agrícola \\
\hline Urbano & Pastoril \\
\hline
\end{tabular}

\section{RESULTADOS E DISCUSSÃO}

Em 1991, o município de Alcobaça contava com uma população de 15.638 habitantes, e em 2010 de 21.271 habitantes, apresentando um crescimento de $36,0 \%$, o que significa 5.633 novos habitantes (IBGE, 2010).

O aumento populacional alcobacense supera o crescimento demográfico da Bahia, que foi de 1,08\% ao ano no mesmo período analisado (IBGE, 2010). A aceleração do crescimento populacional decorre dos fluxos migratórios positivos de outros municípios e estados, atraídos pelas perspectivas de emprego na indústria de celulose, e também da redução dos níveis de mortalidade e aumento na taxa de natalidade.

Como consequência das transformações econômicas e do início do processo de concentração fundiária do território alcobacense pela monocultura do eucalipto, percebem-se aumentos no crescimento demográfico de 3.280 habitantes $(3,6 \%$ ao ano) nas zonas rurais no período de 1991-

$\begin{array}{llllll}\text { Caminhos de Geografia } & \text { Uberlândia } & \text { v. 20, n. } 72 & \text { Dez/2019 } & \text { p. 454-471 } & \text { Página } 457\end{array}$


2000. Entre os anos 2000-2010, mesmo havendo aumento absoluto da populacional municipal, registrou-se uma relevante perda nas populações rurais, apresentando déficit demográfico de 3.268 habitantes, ou seja, houve uma redução da população à taxa de $2,4 \%$ ao ano nesse período, enquanto a população urbana aumentou nos anos de 1991-2010, com 5.621 novos habitantes na zona urbana (Tabela 1).

Tabela 1 - População total, urbana e rural do município de Alcobaça/BA.

\begin{tabular}{c|c|c|c|c|c}
\hline \multicolumn{2}{c|}{1991} & \multicolumn{2}{c|}{2000} & \multicolumn{2}{c}{2010} \\
\hline Rural & Urbano & Rural & Urbano & Rural & Urbano \\
\hline 10.174 & 5.464 & 13.454 & 7.446 & 10.186 & 11.085 \\
\hline \multicolumn{2}{c|}{15.638} & \multicolumn{2}{c|}{20.900} & \multicolumn{2}{c}{21.271} \\
\hline \multicolumn{3}{c}{ Fonte: IBGE $(1991,2000$ e 2010). }
\end{tabular}

O decrescimento da população rural se deve a essa nova "matriz de produção agrícola" com base na silvicultura. A monocultura do eucalipto (Figura 2) tem alcançado altos índices de produtividade e utilizado tecnologia de ponta no que diz respeito a manejo, mecanização, mão de obra especializada e variedades extremamente adaptadas (clones). Além disso, se beneficiam de aspectos inerentes à localização no município para obter ganhos de eficiência na logística de transporte de madeira até os locais de processamento em localidades vizinhas.

Figura 2 - Área ocupada por eucalipto

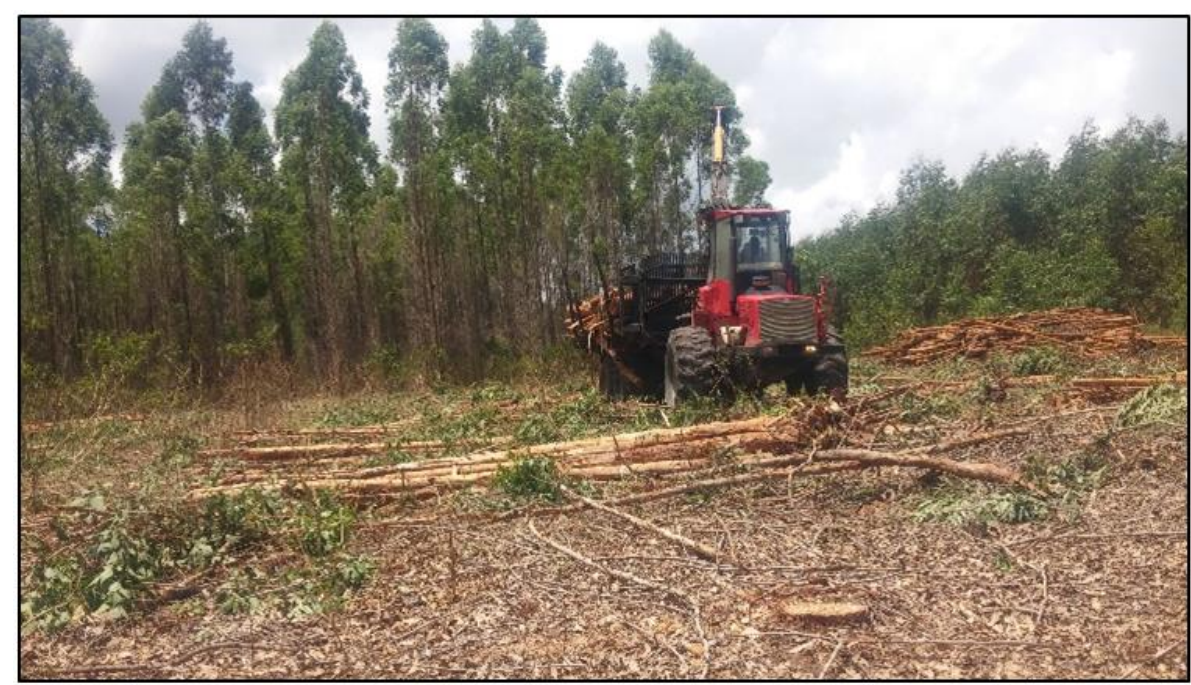

Pedreira (2008) afirma que, segundo relato de um morador da região, à medida que o cultivo do eucalipto avançava, reduzia no campo tanto o emprego temporário quanto o permanente. Dessa forma, desde a entrada do eucalipto na década de 80 , observa-se um crescimento significativo da população urbana em detrimento daquele do meio rural.

O avanço do eucalipto nas áreas agricultáveis, que seriam passíveis de serem utilizadas pela agricultura familiar, desencadeou o processo de expulsão da população rural, no momento em que não há mais terras agricultáveis e os trabalhadores do campo sentem-se atraídos (obrigados) a buscar novas oportunidades de trabalho. No entanto, esse trabalhador não consegue se inserir no mercado de trabalho, uma vez que as novas atividades exigem cada vez mais mão de obra qualificada. Este é um dos fatores que têm contribuído no avanço de movimentos sociais rurais em Alcobaça.

\begin{tabular}{|c|c|c|}
\hline Caminhos de Geografia & Uberlândia & v. 20, n. 72 \\
\hline
\end{tabular}


Inevitável observar que essa nova matriz acabou deslocando os pequenos agricultores e extrativistas para núcleos rurais já existentes e criando novas comunidades. Como ilustrado na Figura 3 atualmente são mais de 38, das quais cinco de origem de movimentos sociais, uma quilombola e uma indígena. A gênese de formação histórica e o surgimento destes cinco assentamentos rurais podem ser entendidos a partir do movimento de expansão conflituosa da monocultura do eucalipto, frente a necessidade de subsistência da população rural de toda a região do Extremo Sul da Bahia que em Alcobaça se percebem e têm condições necessárias para a organização de movimentos de retomada da terra.

Figura 3 - Mapa das comunidades do município de Alcobaça (BA).

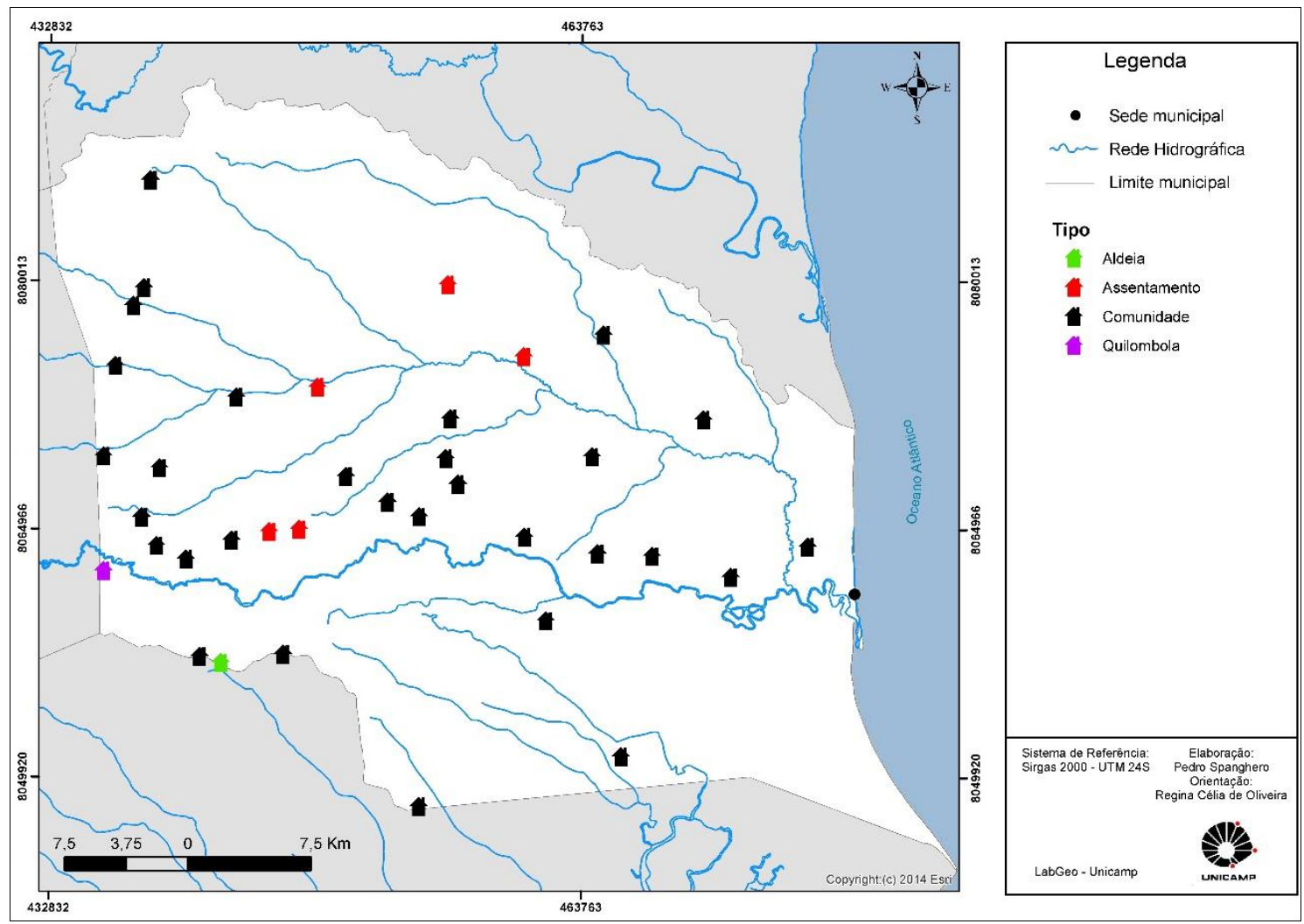

A produção agrícola familiar distribui-se em $50 \mathrm{~km}^{2} \mathrm{com}$ mandioca, fruticultura, café, urucum, pimenta e outras culturas (IBGE, 2010). A silvicultura ocupa aproximadamente $594,9 \mathrm{~km}^{2}$, entre plantio e reservas. As demais, como pode ser observado em campo são destinadas a Áreas de Preservação Permanente (APPs) e pastos com baixo poder de lotação.

Segundo o levantamento do IBGE (2010), o Produto Interno Bruto (PIB) alcobacense demonstra que o setor agropecuário, no qual se insere a silvicultura, é responsável por $28 \%$ do PIB de $\mathrm{R} \$ 198.499 .000$ reais. Enquanto que o setor de serviço, que em grande parte corresponde à atividade turística, representa $30 \%$ de participação e o setor industrial apenas $4 \%$. Os recursos provenientes dos órgãos estaduais e federais somados aos impostos representam $37 \%$.

As principais atividades econômicas de Alcobaça são a silvicultura, o turismo, a agricultura e a pesca. Vale ressaltar o importante papel da atividade pesqueira na geração de renda de centenas de famílias do município (sede) e a agricultura de subsistência na organização socioeconômica de famílias rurais carentes.

A vulnerabilidade social, alinhada ao processo de monopolização do território por parte da monocultura de eucalipto desde o final da década de 70 , foi responsável pela elevada taxa de desemprego estrutural, com decréscimo populacional rural, aumento significativo nos índices de urbanização regional e sérias transformações sociais de produção. 
A demanda de trabalho permanente para manutenção da área plantada com eucalipto é de um trabalhador por 20 hectares/ano. No caso de fruticultura, atividade agrícola que gera mais empregos por hectare, a demanda seria de cinco trabalhadores por hectare/ano, o que torna a atividade 100 vezes mais geradora de empregos que a silvicultura de eucalipto (DE'NADAI, 2005).

Mesmo apresentando graves problemas de concentração de renda e baixíssimos índices socioeconômicos, a renda per capita média de Alcobaça apresentou crescimento de 156,94\% nas últimas duas décadas, passando de $R \$ 123,28$, em 1991, para $R \$ 230,22$, em 2000, e para $R \$$ 351,75 , em 2010. Junto com o crescimento médio da renda, a proporção de pessoas de baixa renda, com renda domiciliar per capita inferior a $R \$ 140,00$, diminuiu e passou de 75,40\%, em 1991, para 46,95\%, em 2000, e para 32,69\%, em 2010 (Tabela 2).

Tabela 2 - Renda, Pobreza e Desigualdade em Alcobaça (BA).

\begin{tabular}{c|c|c|c}
\hline & $\mathbf{1 9 9 1}$ & $\mathbf{2 0 0 0}$ & $\mathbf{2 0 1 0}$ \\
\hline Renda per capita & 123,28 & 230,22 & 351,75 \\
\hline $\begin{array}{c}\text { Extremamente pobres com } \\
\text { renda }<\mathrm{R} \$ 70,00(\%)\end{array}$ & 48,13 & 22,12 & 13,94 \\
\hline $\begin{array}{c}\text { Pobres com renda } \\
\mathrm{R} \$ 140,00(\%)\end{array}$ & 75,40 & 46,95 & 32,69 \\
\hline $\begin{array}{c}\text { Rendimento médio } \\
\text { Ocupados com rendimento de até 1 s.m. }-18\end{array}$ & $\mathbf{2 0 0 0}$ & $\mathbf{2 0 1 0}$ \\
\hline $\begin{array}{c}\text { anos ou mais (\%) } \\
\text { Och, }\end{array}$ & 47,18 \\
\hline
\end{tabular}

Fonte: IPEA (2013).

O aumento do PIB total e da renda per capita não significa que a população se beneficiou desse crescimento, ou que houve mudanças significativas em seu padrão de vida. Mesmo com melhorias, a renda per capita nominal foi inferior à média estadual de $R \$ 773,00$. A melhoria na renda municipal deve-se em grande parte à dependência da administração pública às políticas de governo de redistribuição de renda, como, por exemplo, o programa Bolsa Família e Programa de Aquisição de Alimentos (PAA), o que demonstra a vulnerabilidade socioeconômica de uma população dependente desses programas, que atualmente vêm sofrendo diversos cortes.

O programa Bolsa Família beneficia aproximadamente três mil e quinhentas pessoas $(16 \%$ da população), contribuindo para a subsistência dos alcobacenses. O PAA é considerado de suma importância na agricultura familiar por auxiliar na comercialização e aquisição de produtos utilizados em grande parte na merenda escolar das escolas municipais. O PAA beneficia mais de 100 famílias, comprando suas produções e possibilitando que muitos tenham uma renda mínima fixa.

Dados disponibilizados pela IPEA (2013) são ainda mais assustadores, pois apontam que $59 \%$ da população alcobacense se encontra em estado de vulnerabilidade à pobreza, ou seja, recebem uma renda domiciliar per capita igual ou inferior a $\mathrm{R} \$ 255,00$ mensais. O número de residências com renda média per capita mensal abaixo de um salário mínimo é de 4.475 domicílios, o que representa mais de $70 \%$ de todos os domicílios alcobacenses (IBGE, 2010).

Ainda que os índices socioeconômicos de Alcobaça tenham evoluído, o município apresenta graves problemas. O rendimento mensal de até um salário mínimo corresponde a mais de $47 \%$ da população economicamente ativa, ou seja, mais de 9.000 pessoas não conseguem atender as suas necessidades básicas. Para efeito de comparação, em dezembro de 2010 o Departamento Intersindical de Estatística e Estudos Socioeconômicos (DIEESE) considerava o salário mínimo necessário a nível nacional de $R \$ 2.227,53$ como o suficiente para suprir um trabalhador e sua família com alimentação, moradia, saúde, educação, vestuário, higiene, transporte, lazer e previdência (DIEESE, 2017).

Observa-se na Tabela 3 que a evolução da desigualdade de renda passou de 0,62, em 1991, para 0,54, em 2000 e para 0,53, em 2010, ano em que o PIB apresentou aumento decorrente do boom das commodities do mercado internacional e teve um crescimento de mais de $300 \%$, ou $R \$ 163.601 .000$ (2000 - 2010), para uma melhoria de apenas 1 ponto neste índice, como observado na Tabela 4. Para

$\begin{array}{llllll}\text { Caminhos de Geografia } & \text { Uberlândia } & \text { v. 20, n. } 72 & \text { Dez/2019 } & \text { p. 454-471 Página } 460\end{array}$


efeito de comparação, no período de 2000-2010, a Bahia teve um aumento 4 pontos no índice de GINI.

Tabela 3 - Índice de GINI de Alcobaça (BA)

\begin{tabular}{c|c|c|c}
\hline Ano & $\mathbf{1 9 9 1}$ & $\mathbf{2 0 0 0}$ & $\mathbf{2 0 1 0}$ \\
\hline Índice de GINI & 0,62 & 0,54 & 0,53 \\
\hline PIB & - & $\mathrm{R} \$ 65.528 .000$ & $\mathrm{R} \$ 218.129 .000$ \\
\hline \multicolumn{2}{r}{ Fonte: PNUB, IPEA (2013). }
\end{tabular}

A Tabela 4 ilustra o Índice de Desenvolvimento Humano Municipal (IDHM) dos anos de 1991, 2000 e 2010. Em 2010 o IDHM chega a 0,608, o que coloca o município de Alcobaça na faixa de Desenvolvimento Humano Médio (IDHM entre 0,600 e 0,699), ou seja, é possível observar a evolução gradual do IDHM.

Tabela 4 - IDHM de Alcobaça (BA).

\begin{tabular}{c|c|c|c}
\hline Componentes & $\mathbf{1 9 9 1}$ & $\mathbf{2 0 0 0}$ & $\mathbf{2 0 1 0}$ \\
\hline IDHM Educação & 0,0078 & 0,271 & 0,476 \\
\hline IDHM Longevidade & 0,563 & 0,631 & 0,771 \\
\hline IDHM Renda & 0,459 & 0,543 & 0,511 \\
\hline IDHM & $\mathbf{0 , 2 7 2}$ & $\mathbf{0 , 4 5 3}$ & $\mathbf{0 , 6 0 8}$ \\
\hline \multicolumn{2}{|r|}{ Fonte: PNUB, IPEA (2013). }
\end{tabular}

De 1991 a 2010, o IDHM de Alcobaça passou de 0,272, em 1991, para 0,608, em 2010, enquanto o IDHM baiano teve um aumento considerável, passando de 0,493 para 0,727. Isso implica em uma taxa de crescimento de $123,53 \%$ para o município, enquanto a Bahia teve um aumento de $47 \%$. No município, o componente que mais cresceu em termos absolutos foi educação, seguida por longevidade e renda.

Desta forma, podemos considerar que existem dois vetores econômicos que predominam na polarização territorial em Alcobaça. O primeiro, destacado na Figura 4, refere-se ao fator imobiliário observado através da compra e construção de segundas casas e condomínios para fins turísticos.

Observa-se na Figura 4 a grande concentração de segundas residências ocupando a maior parte da planície marinha, próxima da linha de costa da zona urbana. Ao todo, são mais de $30 \%$ de toda zona urbana preenchida com segundas residências. Além disso, é possível citar as novas construções destinadas a empreendimentos turísticos tais como hotéis e condomínios na porção norte da zona urbana.

O segundo vetor é a apropriação da terra pela monocultura de eucalipto, referentes ao uso e ocupação da terra, evidenciando o avanço das áreas ocupadas pela silvicultura (Figura 5). 
Figura 4 - Densidade populacional da área urbana de Alcobaça (BA).
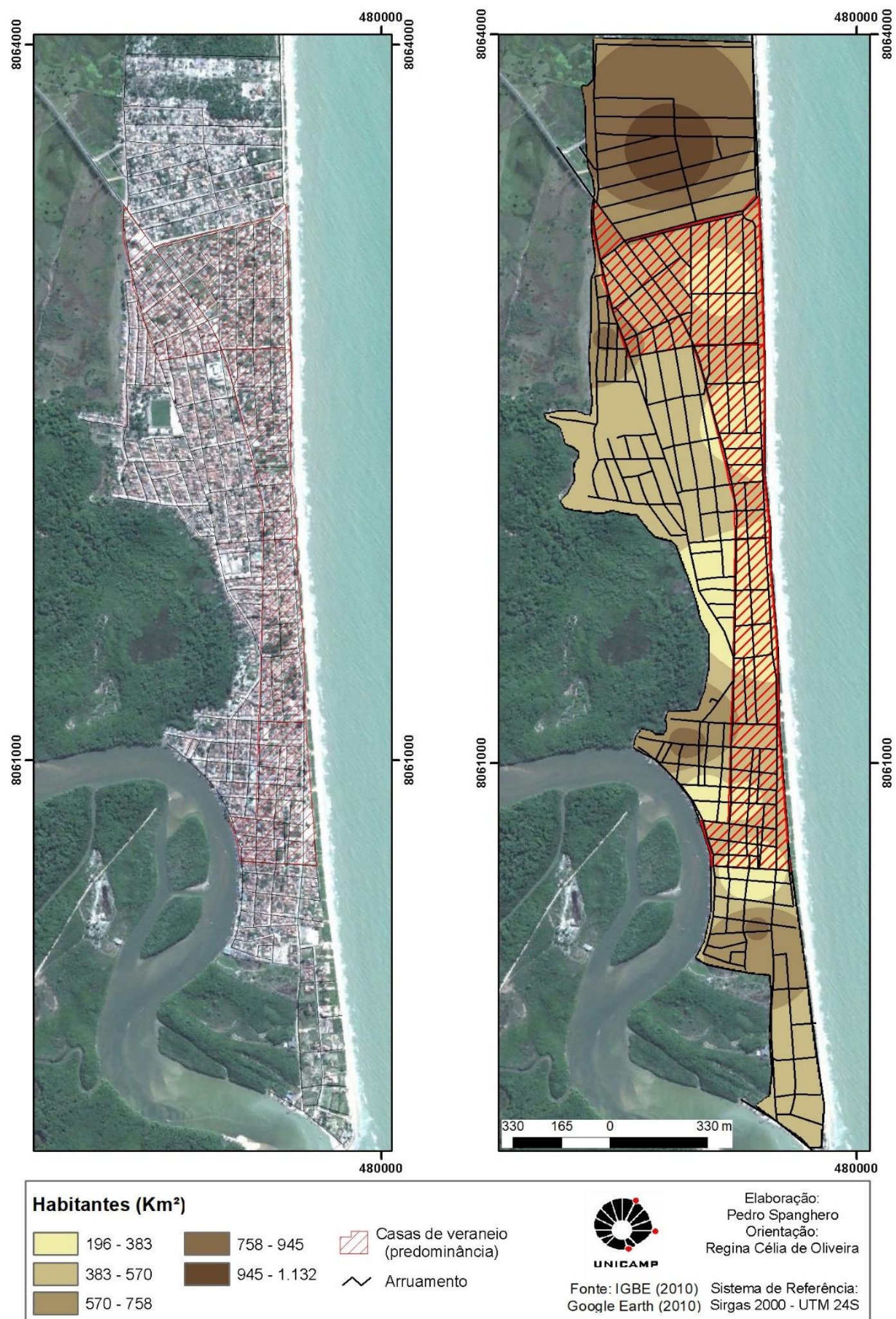
Figura 5 - Uso e ocupação da terra do município de Alcobaça (BA) em escala temporal.
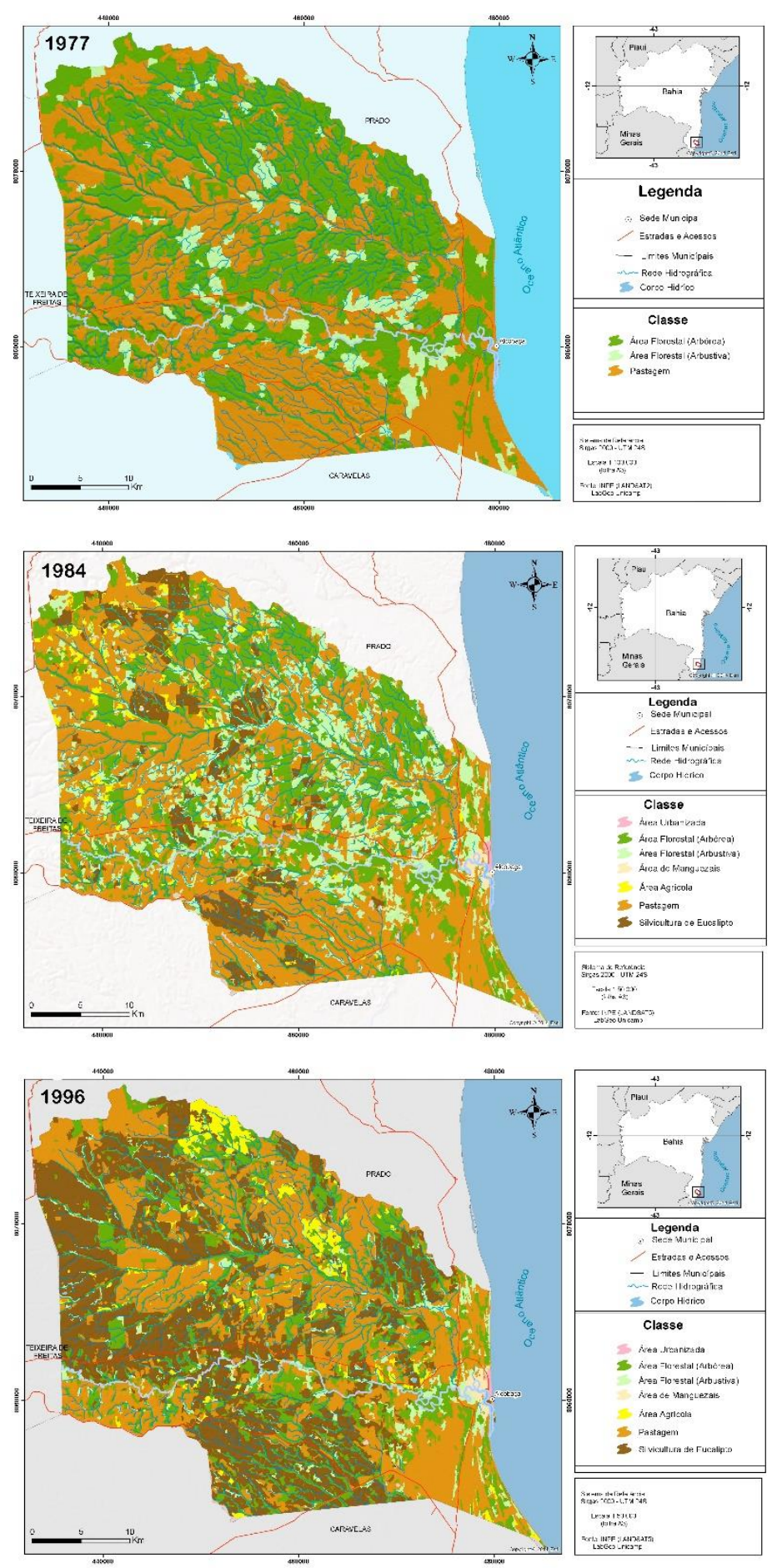


\section{Cont. Figura 5}
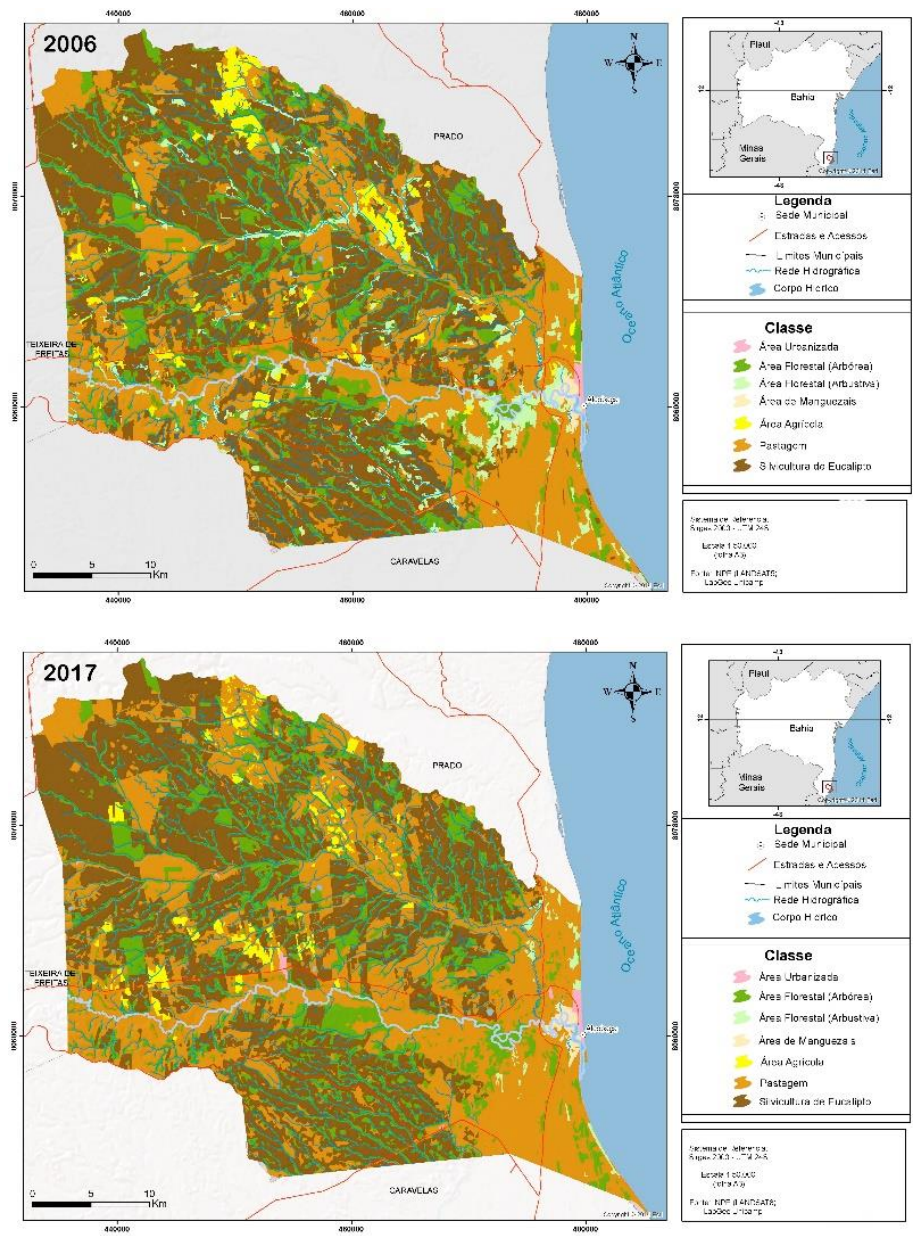

Desta forma, pode-se representar na Figura 6 a evolução das classes de uso e ocupação da terra em seus respectivos anos.

É possível considerar que a matriz atual da paisagem é composta pela atividade Silvipastoril, já que mais de $75 \%$ do território alcobacense é ocupado por estas duas atividades (pecuária e silvicultura). A monocultura de eucalipto foi a classe que mais apresentou aumento ao longo das quatro décadas analisadas.

Ao longo dos anos, a área florestal arbórea foi a classe que mais diminuiu: representava $45 \%$ em 1977 e em 2017 apenas $20 \%$ da área total, o que significa uma diminuição de $44 \%$ em sua área total. Atualmente grande parte desta classe encontra-se localizada em áreas de APPs e reservas legais. O mesmo vale para a área florestal arbustiva, que vem apresentando diminuição ocasionada pela preservação dessas áreas em tempos pretéritos e transformação em uma cobertura arbórea. As áreas de manguezais, consideradas pela Lei ํㅡ 12.651/2012 como áreas protegidas, foram a classe natural que sofreu menor alteração ao longo dos anos.

Em contrapartida, a classe de maior crescimento no mesmo período foi a silvicultura de eucalipto. Observa-se que em 2017 esta monocultura ocupava 37\% $\left(561 \mathrm{~km}^{2}\right)$ do território, embora esta classe não existisse no município de Alcobaça em 1977, demonstrando a rápida ocupação do território pelo eucalipto. Desta forma, observando a figura 7 é possível comparar dois períodos distintos para entender como era a paisagem em 1977 e quais áreas o eucalipto ocupava em 2017. O Mapa de uso e ocupação da terra de 1977 com sobreposição das áreas de eucalipto do ano de 2017 registra a comparação desses dois períodos.

\begin{tabular}{|c|c|}
\hline Caminhos de Geografia & Uberlândia \\
\hline
\end{tabular}


Figura 6 - Distribuição percentual do uso e ocupação da terra do município de Alcobaça (BA) (1977 2017).

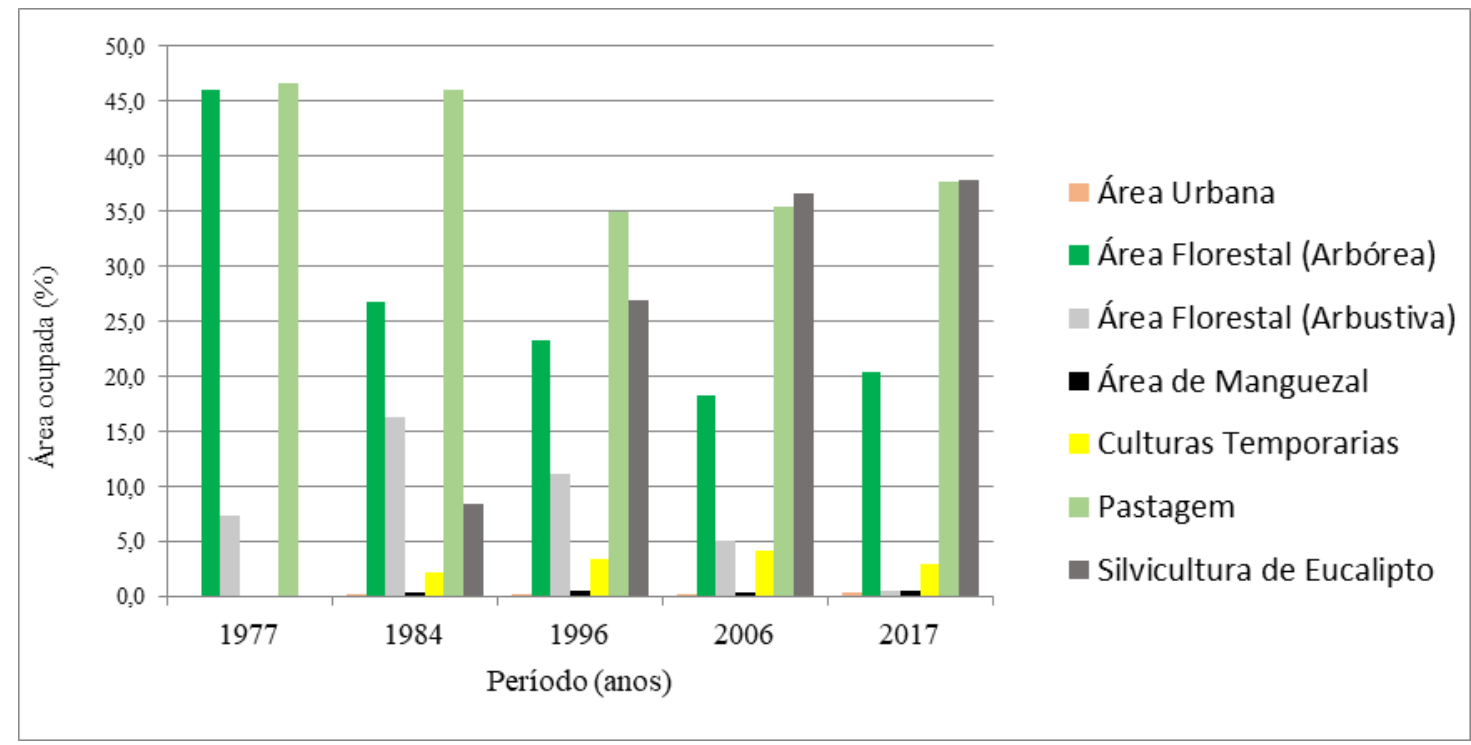

Figura 7 - Mapa de uso e ocupação da terra de Alcobaça (BA) dos anos de 1977 com sobreposição das áreas de eucalipto do ano de 2017.

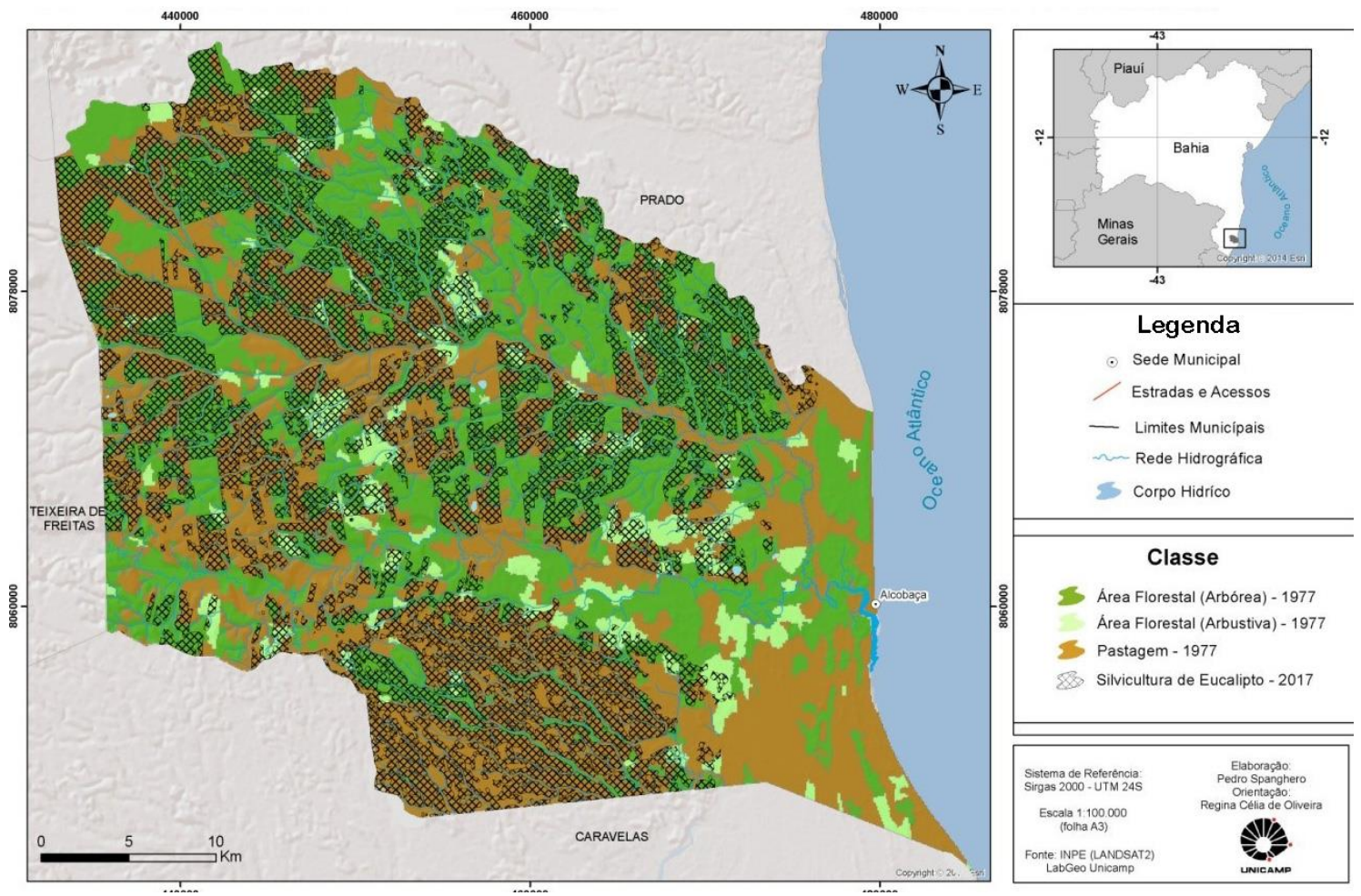

A análise comparativa do uso e ocupação da terra de Alcobaça em 1977 e em 2017 indica que correspondia a $260 \mathrm{~km}^{2}$ de cobertura vegetal (vegetação Arbórea e Arbustiva) e $275 \mathrm{~km}^{2}$ de pastagem. Isso evidencia a transformação da paisagem, que ocorre via desmatamento, por conta da necessidade de atender os interesses dos silvicultores. 
Pedreira (2004) aponta alguns fatores que desencadearam a expansão da silvicultura de eucalipto do norte do Espírito Santo em direção ao sul da Bahia. O primeiro fator foi o movimento de integração econômica do Brasil, que atingiu esta porção do território principalmente após a inauguração da BR 101, em 1973. Rompeu-se, então, com o isolamento físico e econômico, tornando este trecho do território baiano uma região produtiva, redefinindo a hierarquia da rede de cidades, ao mesmo tempo em que impulsionou uma série de transformações na estrutura socioeconômica.

Considerando que o conceito de Sistema Antrópico abarca a junção entre a forma de usar e ocupar o território, associada às demais características socioeconômicas e à evolução temporal do uso e ocupação da terra e dos agentes de transformação urbanos e rurais, como as comunidades tradicionais e seus respectivos modos de vida, apresentam-se na Figura 8 os sistemas antrópicos identificados no município de Alcobaça.

Os Sistemas Antrópicos foram organizados em três grupos, diferenciados a partir das características de uso e ocupação do território alcobacense.

Figura 8 - Mapa de Sistemas Antrópicos do município de Alcobaça (BA).

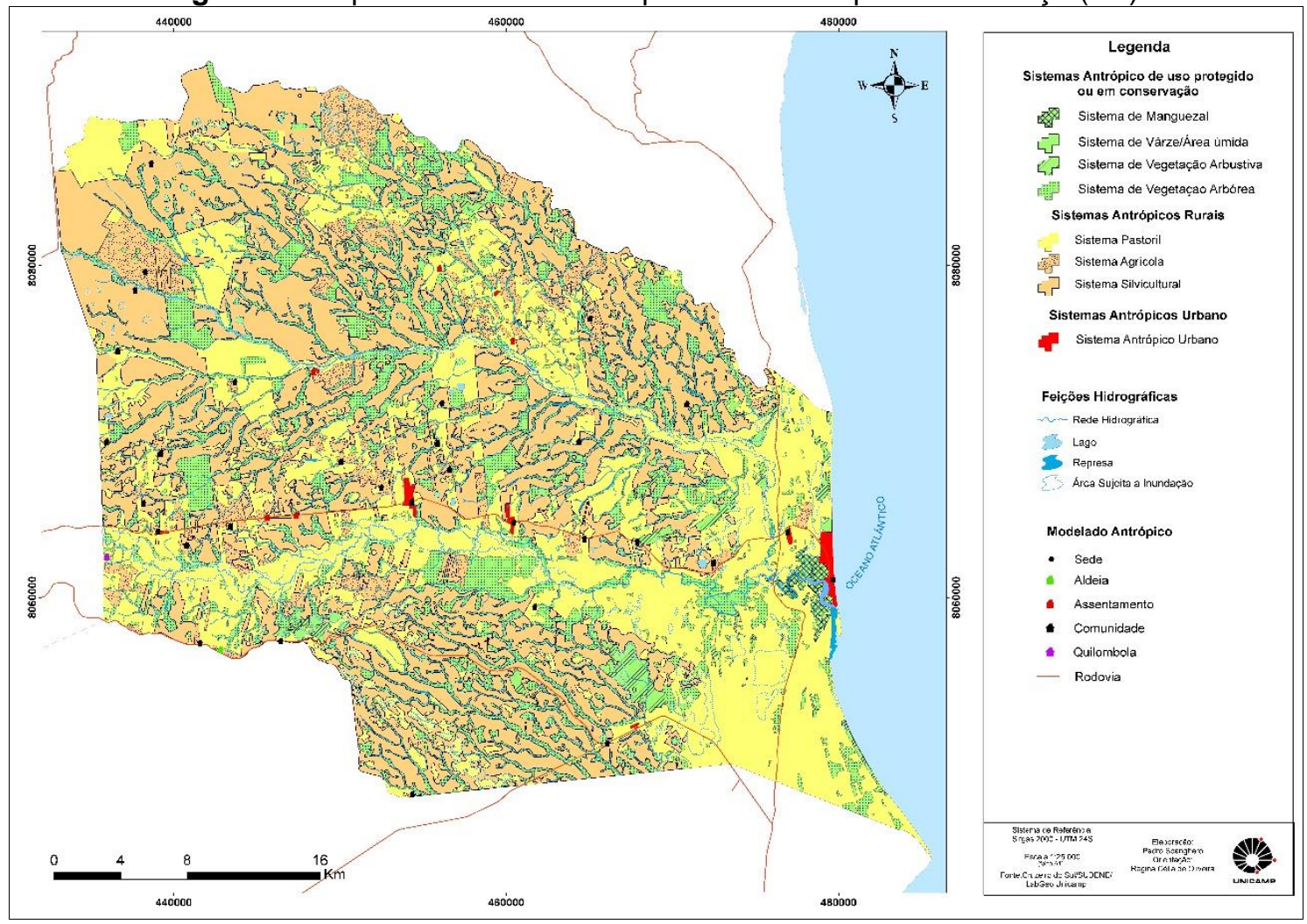

O Sistema Antrópico de Uso Natural Protegido ou em Conservação é constituído por sistemas florestais naturais associados ao Domínio da Mata Atlântica que, no decorrer do processo de uso e ocupação da terra, foi transformado em área de uso antrópico, que hoje representa aproximadamente $330 \mathrm{~km}^{2}$, ou apenas $22 \%$ do município (Fligura 6). O Sistema acima mencionado é composto por 4 subsistemas que são considerados áreas de preservação permanente protegidos pelas leis nำ12.651 de 2012 (Código Florestal) e n-11.425 de 2006.

O primeiro subsistema é o Sistema Manguezal, representando pela Figura 9 e recobre $6,2 \mathrm{~km}^{2} \mathrm{da}$ área total, cerca de apenas $0,4 \%$ do município. Este subsistema está localizado no ambiente estuarino do Rio Alcobaça e é caracterizado como um ecossistema litorâneo que ocorre em áreas de influência fluviomarinha, formado por terrenos lodosos e arenosos. Apresenta grandes quantidades de nutrientes, o que o torna um grande produtor primário e um berçário natural de inúmeras espécies de peixes e crustáceos. É tido como uma valiosa fonte de renda para a população caiçara.

$\begin{array}{llllll}\text { Caminhos de Geografia } & \text { Uberlândia } & \text { v. 20, n. } 72 & \text { Dez/2019 } & \text { p. 454-471 Página } 466\end{array}$


Neste subsistema existe uso direto por parte dos pescadores artesanais dos recursos produzidos, que representa a captura artesanal de peixes, ostras, mariscos, camarões, siris, caranguejos e guaiamuns, que é a base econômica da população caiçara do município.

Portanto, a efetiva conservação deste subsistema antrópico é estratégica para a sobrevivência da comunidade de mais de 1.900 pescadores e marisqueiras, que residem ou utilizam direta ou indiretamente a região estuarina com mais de 500 embarcações destinadas à pesca, tornando o porto de Alcobaça um dos maiores da Costa das Baleias.

Outro subsistema que faz parte do Sistema Antrópico de Uso Natural Protegido ou em Conservação é o Subsistema de Várzea/Área Úmida, caracterizado por ocupar uma área de 4,7 km², ou apenas $0,3 \%$ do município. Este subsistema apresenta-se periodicamente alagado devido ao transbordamento lateral dos cursos d'águas nas áreas de planície fluvial e nas zonas de planície marinha, decorrente da precipitação pluviométrica ou do afloramento do lençol freático.

Figura 9 - Subsistema de Manguezal.

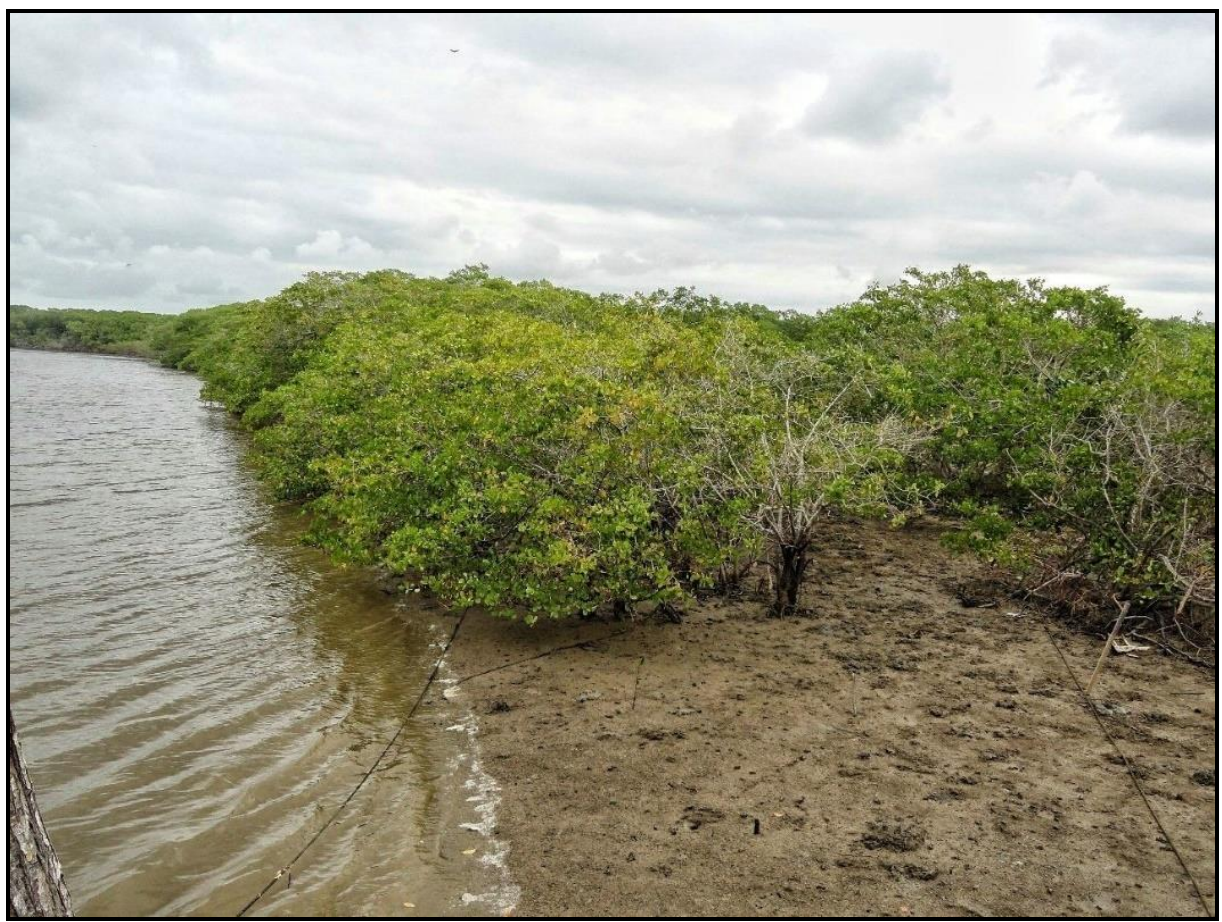

A grande relevância a ser evidenciada para esse subsistema é o valor dos serviços ambientais que eles proporcionam para a sociedade e para o meio ambiente, destacando-se a estocagem da água, a recarga do lençol freático, a regulagem do clima local, a manutenção da biodiversidade, a regulagem dos ciclos biogeoquímicos, a estocagem de carbono e o habitat para inúmeras espécies, endêmicas ou não. Adicionalmente, esses ambientes oferecem ainda inúmeros subsídios para as populações humanas tradicionais, tais como a pesca, a agricultura de subsistência, e a pecuária extensiva (JUNK et al. 2012).

Os subsistemas de Vegetação Arbustiva e Vegetação Arbórea correspondem, juntos, à maior porcentagem de área ocupada pelo Sistema Antrópico de Uso Natural Protegido ou em Conservação, sendo distribuídos respectivamente em 32 km² (2\%) e 290,6 km² (19,60\%).

O subsistema de Vegetação Arbustiva corresponde a fragmentos da Mata Atlântica que sofreram com o processo de antropização e corte seletivo de árvores, e atualmente apresenta-se em processo de regeneração, enquanto o Subsistema de Vegetação Arbórea é composto por boa parte de fragmentos preservados da Mata Atlântica, localizados em grande parte em áreas de APP.

$\begin{array}{lllll}\text { Caminhos de Geografia } \quad \text { Uberlândia } & \text { v. 20, n. } 72 & \text { Dez/2019 } & \text { p. 454-471 Página } 467\end{array}$


Entretanto, grande parte desses fragmentos vem sofrendo pressão antrópica devido a suas valiosas madeiras. Infelizmente, não há fiscalização eficiente que venha a proteger de fato estes últimos fragmentos florestais, já que a fiscalização ambiental é ineficaz e não há qualquer tipo de unidade de conservação pública ou privada de uso restrito que possa vir a garantir a preservação daqueles. Nos trabalhos de campo foram comprovados diversos impactos ambientais, como a supressão gradativa de áreas de preservação permanente.

As áreas que representam grande riqueza em seus ecossistemas e que estão sob qualquer tipo de ameaça são instituídas como áreas protegidas. No entanto, o que se observa no município de Alcobaça é a sua descaracterização antes mesmo da implementação da legislação e descumprimento desta, pois há o constante desrespeito dos limites legais e ausência de uma fiscalização efetiva.

O estudo dos Sistemas Antrópicos Urbanos e dos Sistemas Antrópicos Rurais deve ser feito de maneira concomitante, pois são nesses Sistemas Antrópicos que predominantemente ocorre o processo de fixação humana e consequentemente se desenvolve grande parte das atividades produtivas da região.

Fazendo uma comparação da representatividade territorial dos Sistemas Antrópicos Rurais, verificase a predominância dos subsistemas Silvicutural e Pastoril em detrimento do subsistema Agrícola. No entanto, os efeitos e ações deste último subsistema são de suma importância para os sistemas ambientais do município.

O contingente populacional do município de Alcobaça vem aumentando desde a segunda metade do século XX. Este fato pode ser comprovado com os dados apresentados na Tabela 2, que ilustra maior crescimento populacional na área urbana, enquanto a zona rural apresentou decréscimo populacional de $-2,4 \%$ ao ano no período de 2000-2010.

Os Sistemas Antrópicos Rurais representam a maior concentração de uso da terra do município, com mais de $1.100 \mathrm{~km}^{2}$ ou $77 \%$ do território, e com uma população de 10.186 habitantes, sendo que a distribuição populacional se concentra principalmente na Rodovia BA-290 e na porção oeste do município, devido a melhor capacidade produtiva do solo e também pela proximidade com a cidade de Teixeira de Freitas para escoar os produtos agrícolas.

O Sistema Pastoril corresponde a mais de $36,6 \%$ da área total, cerca de $541,7 \mathrm{~km}^{2}$. Esse subsistema emprega um caráter fundiário concentrador e é composto por grandes áreas de pasto degradado, com elevada perda de solos. O uso da terra com pastagem provoca problemas ambientais como pisoteio do solo pelo gado, que o compacta e reduz a capacidade de infiltração da água.

As terras com pastagens são utilizadas principalmente para a pecuária voltada exclusivamente para gado de corte, com aproximadamente 37.000 cabeças (IBGE, 2010). Existem, ainda, algumas áreas algumas áreas com criação de búfalos, que apesar de pequenas, contribuem para o incremento do rebanho do município, aumentando a ocupação dos terrenos mais problemáticos, como é o caso das áreas de planícies fluviais do rio Alcobaça e do rio Itaitinga.

Na produção agrícola disponibilizada pelo IBGE (2016) percebe-se um predomínio dos cultivos de lavouras permanentes, com destaque para a produção de mamão (Carica papaya), que rendeu 28.620 toneladas, ocupando $3 \%$ da área total colhida, e que gerou a maior renda agrícola do município, de $R \$ 21.465,00$ (Figura 10). Outro cultivo que se destaca é o da pimenta-do-reino (Piper nigrum), com elevada rentabilidade a partir de uma área ocupada de apenas 100 ha, que obtém a segunda maior renda municipal no valor de $\mathrm{R} \$ 6.864$ mil.

A produção de coco-da-baía (Cocos nucifera) ocupa 40\% do total de área de produção agrícola e gera a terceira maior renda, de $\mathrm{R} \$ 4.860$ mil. Outros cultivos menores, tais como o maracujá (Passiflora edulis), o urucum (Bixa orellana), o café (Coffea), dentre outras lavouras tiveram um peso importante como fonte de renda para a agricultura familiar e para a geração de emprego.

A produção de mandioca (Manihot esculenta) alcobacense se destaca em toda a região do Extremo Sul da Bahia, com a existência de mais de 200 farinheiras que comercializam seus produtos para toda a região e para outros estados.

Grande parte da produção de mandioca, se não toda, advém da agricultura familiar, sendo, portanto, a produção de farinha de mandioca uma das formas que a agricultura familiar encontrou de agregar

$\begin{array}{llllll}\text { Caminhos de Geografia } & \text { Uberlândia } & \text { v. 20, n. } 72 & \text { Dez/2019 } & \text { p. 454-471 Página } 468\end{array}$


valor à mandioca; no entanto, vale destacar as condições mínimas e precárias de trabalho com pouca tecnologia empregado nas farinheiras e sua forma majoritariamente artesanal.

Figura 10 - Produção de mamão (Carica papaya)

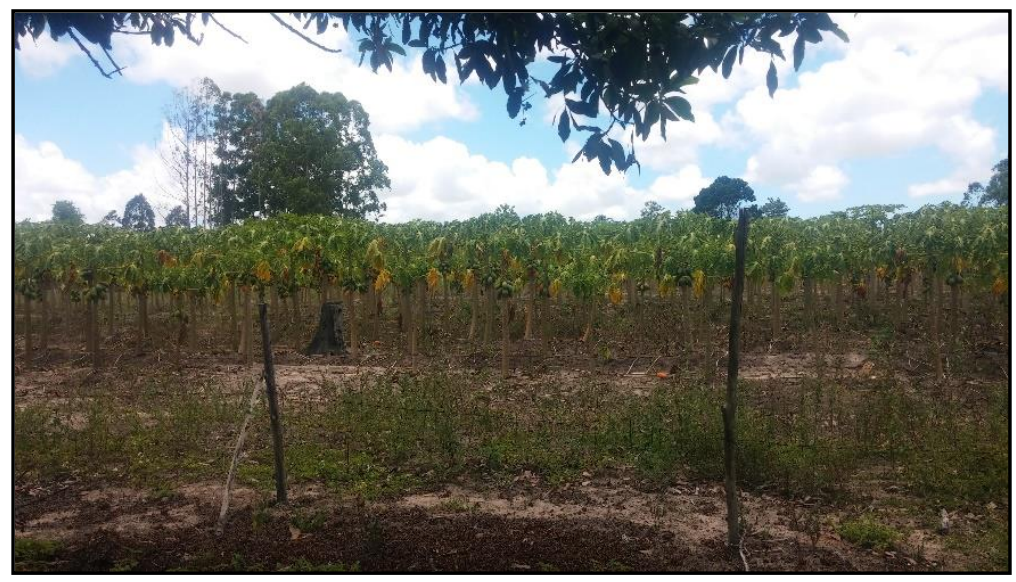

Dentro dos Sistemas Antrópicos Rurais, o Subsistema Silvicultura ocupa uma área de $594,9 \mathrm{~km}^{2}$ ou $40 \%$ de todo território alcobacense, correspondendo à maior atividade desenvolvida em Alcobaça.

Este subsistema compreende a cultura do eucalipto de propriedade da Fíbria Celulose, representado por plantios clonais de eucaliptos, que são distribuídos em grandes manchas em todo o município, ocupando principalmente as partes altas e mais planas dos Tabuleiros Costeiros, o que facilita o processo de mecanização e manejo do eucalipto.

Percebe-se que os empreendimentos de celulose e papel alteraram a paisagem regional e promoveram uma nova organização do espaço e, principalmente, dos fatores socioeconômicos, imputando ao Extremo Sul da Bahia uma nova lógica de crescimento econômico (CAR, 1994). Assim, considerando o crescente avanço das áreas de eucaliptais, pode-se fazer uma correlação direta dessa produção com a disponibilidade de terras no espaço rural destinadas à agricultura, já que as empresas do ramo de papel e celulose necessitam de grandes áreas para reflorestamento (ALMEIDA, et al., 2008).

Neste contexto, a ocupação intensiva de vastas áreas rurais, através da monocultura de eucalipto, conquistou terras antes destinadas à agropecuária, em especial pequenas propriedades com culturas alimentares (CAR, 1994). Com grande processo de mecanização e pressão sobre os pequenos agricultores, atualmente a monocultura de eucalipto utiliza mais de $60 \%$ e a pecuária $15 \%$, totalizando $75 \%$ das melhores áreas agricultáveis do município.

A expansão da silvicultura de eucalipto teve início nas áreas limítrofes com o estado do Espírito Santo, expandindo-se, ao longo da década de 1980, em direção ao município de Alcobaça. Atualmente, embora as atividades de pesca e agricultura de subsistência ocupem um peso importante na estrutura socioeconômica do município, a atividade da monocultura de eucalipto constitui o vetor mais representativo da economia alcobacense, sendo o principal responsável pelo aumento nas arrecadações e melhorias nos índices econômicos ao longo dos anos.

Para Teixeira e Guerra (2000), a produção de celulose e o manejo de florestas homogêneas costumam representar uma alternativa produtiva, mas há um contato conflituoso com outras atividades como abastecimento de água, turismo ou ainda as diversas formas de utilização da terra e de recursos hídricos. O embate com outras atividades está correlacionado principalmente às grandes áreas que esta atividade ocupa, e ainda ocupará, levando os demais Sistemas Antrópicos, principalmente o subsistema agrícola, a um processo de retração. Além disso, há embates nessa relação, pois a implantação da monocultura de eucalipto pode gerar impactos no município ligados ao solo e aos recursos hídricos, bem como poluição através da produção de celulose.

Mesmo que essas questões de manejo de solo e recursos estejam em jogo, alguns autores evidenciam aspectos positivos da silvicultura de eucalipto quando se compara a atividade com outros impactos antrópicos como, por exemplo, a criação de pastos.

$\begin{array}{llllll}\text { Caminhos de Geografia } & \text { Uberlândia } & \text { v. 20, n. } 72 & \text { Dez/2019 } & \text { p. 454-471 Página } 469\end{array}$


Lima (2004) revelou que em bacias degradadas o uso do eucalipto parece promover, com o devido tempo, um adequado controle dos processos de escoamento superficial e erosão, e uma maior ciclagem de nutrientes, contribuindo, dessa forma, para a melhoria da qualidade da água produzida no local.

Mesmo assim, ainda existem vários aspectos negativos de ordem ecológica e social. Vale ressaltar que o plantio de eucalipto se dá pela inserção de espécies exóticas e transgênicas, fato que por si só compreende um grande choque ao desenvolvimento ambiental local. Sabe-se que as espécies exóticas invasoras têm um significativo impacto na biodiversidade do ambiente, e o processo é considerado como a segunda maior ameaça à perda de biodiversidade (ESPÍNOLA e FERREIRA, 2007), pois afeta diretamente as com Sistemas Ambientais, a economia e a saúde humana, levando à alterações dos ciclos hidrológicos e de nutrientes, bem como a destruição de características peculiares e a alteração nas propriedades ecológicas essenciais.

\section{CONSIDERAÇÕES FINAIS}

Conforme os dados e as discussões levantadas pela pesquisa, percebeu-se mudanças de forma significativa na dinâmica de uso e ocupação no município de Alcobaça durante os últimos anos, devido à incapacidade de implantação de um sistema de planejamento socioambiental adequado que possa contribuir de forma eficiente na melhoria de vida da população. A falta de políticas públicas desencadeia na expansão dos Sistemas Antrópicos Rurais, com destaque ao Sistema Antrópico Silvipastoril em detrimentos dos Sistemas Agrícolas e mais especificamente os Sistemas Antrópico de Uso Protegido ou em Conservação.

Referendando-se na abordagem sistêmica aplicada pelos autores supracitados como princípio teóricometodológico, apresenta-se como uma solução para a análise de forma integrada da paisagem sendo adequada para o entendimento das complexas relações dos Sistemas Naturais e Antrópicos. O ideário sistêmico demonstra também ser uma ferramenta eficaz, pois auxilia na proposição de medidas de controle e mitigação de efeitos ambientais negativos em áreas costeiras.

Prova disso, são os estudos sistêmicos do litoral, que por ser um ambiente de extrema fragilidade ambiental, ao sofrer a interferência antrópica-manifesta nas diversas formas inadequadas de uso e ocupação, responde através de impactos ambientais adversos, sendo necessárias propostas de gestão integrada que favoreçam de fato os limites ambientais existentes.

A metodologia proposta para este trabalho, apoiada na utilização de técnicas de geoprocessamento, sensoriamento remoto e trabalho de campo, mostrou-se eficaz para uma análise integrada do município de Alcobaça, que permitiram a obtenção e análise dos dados geoespaciais. Portanto, a adoção da escala de análise 1:50.000 possibilitou fazer uma análise integrada das ações de manutenção dos sistemas ambientais e o planejamento de novas estratégias.

\section{AGRADECIMENTOS}

Agradecimento a CAPES pela concessão da bolsa de mestrado e a Unicamp pela estrutura.

\section{REFERÊNCIAS}

ALMEIDA, P. J. P. ; PEREIRA, M. L. A. ; SILVA, T. V. B. S. ; PEREIRA, T. C. J. ; SANTOS, A. B. ; SANTOS, E. J. ; OLIVEIRA, L. N. ; AZEVEDO, S. T. ; AUGU, C., 2008. Economic performance of santa inês sheep fed with meskit (Prosopis juliflora) pod meal. Zootech 2008, 26 a 30 de maio de 2008 João Pessoa, PB UFPB/ABZ

AMORIM, R. R. Análise geoambiental como subsídio ao planejamento no uso e ocupação das terras da zona costeira da região Costa do Descobrimento (Bahia). 2011. 283 p. Tese (doutorado) Universidade Estadual de Campinas, Instituto de Geociências, Campinas, SP, 2011.

CAR - Companhia de Desenvolvimento e Ação Regional. Política de Desenvolvimento para o Extremo Sul da Bahia. Salvador: CAR, 1994 (Série cadernos da CAR, n. 3).

DE'NADAI, et al. Promessas de emprego e destruição de trabalho o caso Aracruz Celulose no Brasil. Montevideo: Movimento Mundial pelas Florestas Tropicais, 2005.

Caminhos de Geografia Uberlândia $\quad$ v. 20, n. $72 \quad$ Dez/2019 $\quad$ p. 454-471 Página 470


DIEESE, Departamento Intersindical de Estatísticas e Estudo Socioeconômicos , Pesquisa Nacional da Cesta Básica de Alimentos Disponível em: <

https://www.dieese.org.br/analisecestabasica/salarioMinimo.html\#2010> Acesso em: 12 set. 2017.

ESPÍNOLA, L. A.; FERREIRA J. J. H.. Especies invasoras: Conceptos, modelos y atributos. Interciencia, v. 32, n. 9, p. 580-585, 2007.

IBGE, Instituto Brasileiro de Geografia e Estatística. Censo 1991. Disponível em:

<https://biblioteca.ibge.gov.br/biblioteca-catalogo?id=782\&view=detalhes>. Acesso em: 12 set. 2017.

Censo 2000. Disponível em: < https://www.ibge.gov.br/estatisticas/sociais/populacao/9663-censodemografico-2000.html?edicao=9771 >. Acesso em: 13 set. 2017.

Censo 2010. Disponível em: <http://censo2010.ibge.gov.br/>. Acesso em: 14 set. 2017.

Manual técnico de Uso da Terra. 2013. 3ํㅡ. Ed. Rio de Janeiro. out. 2017.

Produção Agrícola Municipal. 2016. Disponível em: <sidra.ibge.gov.br/pesquisa>. Acesso em: 12

INPE - Instituto Nacional de Pesquisas Espaciais. Imagens Landsat 8 2017. São José dos Campos, 2017.

IPEA - Instituto de Pesquisa Economica Aplicada. Indicadores - Pobreza, distribuição e desigualdade de renda de 1995 a 2015. Disponível em

$<$ http://www.ipea.gov.br/retrato/indicadores pobreza distribuicao desigualdade renda.html $>$. Acesso em: 12 out. 2018.

JUNK, W.J.;PIEDADE, M.T.F.;SCHONGART, J.;WITTMANN, F.. A classification of major natural habitats of Amazonian white-water river floodplains (várzeas). Wetlands Ecology and Management, v. 20, n. 6, p. 461475, 2012. https://doi.org/10.1007/s11273-012-9268-0

LIMA, W. “O eucalipto seca o solo?”. Sociedade Brasileira de Ciências do Solo, v. 29, n. 1, 2004.

MIN - Ministério da Integração Nacional, Anuário Brasileiro de Desastres Naturais 2012. Disponível em: $<$ http://mi.gov.br/c/document library/get file?uuid=f22ccccd-281a-4b72 84b3-

654002cff1e6\&groupld=185960 $>$. Acesso em: 05 de Mar. De 2019

MMA - Ministério do Meio Ambiente. Imagens Rapideye 2017. Satellite Imagery Product Specifications. Disponível em: <www.geocatalogo.mma.gov.br>. Acesso em 10 de dez. 2018.

NICOLODI, J.L.; PETERMANN, R.M. Mudanças Climáticas e Vulnerabilidade da Zona Costeira do Brasil: aspectos ambientais, socieias e tecnológicos. Revista da Gestão Costeira Integrada, v. 10, n. 2, p. 151-177, 2010. https://doi.org/10.5894/rgci206

PEDREIRA, M. S. O complexo florestal e o extremo sul da Bahia: inserção competitiva e transformações socioeconômicas na região. 2008. 164f. Tese (Doutorado em Ciências Sociais em Desenvolvimento, Agricultura e Sociedade). UFRRJ. Rio de Janeiro. 2008.

RODRIGUEZ, J. M. M.; SILVA, E. D.; CAVALCANTI, A. P. B. Geoecologia da paisagem: uma visão geossistêmica da análise ambiental. Fortaleza: EDUFC, 2013.

SEI - Superintendência de Estudos Econômicos e Sociais da Bahia. Anuário estatístico da Bahia. V. 1. Salvador: SEI, 2012.

SETUR/BA - Secretaria de Turismo do Estado da Bahia, PRODETUR NE-II - Costa das Baleia. Disponível em: <http://www.setur.ba.gov.br/arquivos/File/PDITSBaleias.pdf>. Acesso em 03 de maio de 2019.

SOUZA, Sirius Oliveira. Proposta de zoneamento geoambiental como subsídio ao planejamento do uso e da ocupação na Região Costa das Baleias (Bahia). 2017. 226 p. Tese (doutorado) - Universidade Estadual de Campinas, Instituto de Geociências, Campinas, SP, 2011.

TEIXEIRA, F; GUERRA, O. Os 50 anos de industrialização baiana: do enigma a uma dinâmica exógena e espasmódica. Bahia Análise \& Dados, v. 10, n. 1, 2000.

Recebido em: 10/01/2019

Aceito para publicação em: 23/08/2019 